\title{
Fecal medicines used in traditional medical system of China: a systematic review of their names, original species, traditional uses, and modern investigations
}

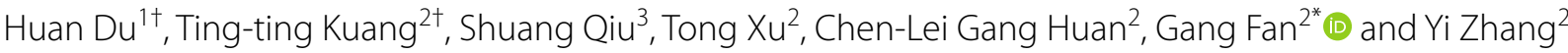

\begin{abstract}
In China, the medical use of fecal matter (fresh fecal suspension or dry feces) can be dated back to the fourth century, approximately 1700 years ago. In long-term clinical practice, Chinese doctors have accumulated unique and invaluable medical experience in the use of fecal materials. In view of their good curative effect and medicinal potential, fecal medicines should be paid much attention. This study aimed to provide the first comprehensive data compilation of fecal medicines used in various Chinese traditional medical systems by bibliographic investigation of 31 medicine monographs and standards. A total of $54 \mathrm{fecal}$ medicines were found to be used in 14 traditional Chinese medical systems. Their names, original species, medicinal forms, and traditional uses were described in detail. These fecal medicines were commonly used to treat gastrointestinal, nervous system, skin, and gynecological diseases. Commonly used fecal medicines include Wu-Ling-Zhi, Jiu-Fen and Hei-Bing-Pian. The information summarized in this study can provide a good reference for the development and utilization of fecal medicines. Further studies are necessary to prove their medicinal value, identify their active ingredients, and elucidate their mechanisms of action so that more people can accept these special medicines.
\end{abstract}

Keywords: Fecal medicines, Traditional Chinese medicine, Gut microbiota, Fecal microbiota transplantation, Gastrointestinal diseases

\section{Background}

Traditional medicines have been used for prevention and treatment of diseases for thousands of years in China. In recent decades, they have attracted worldwide attention due to their reliable therapeutic efficacy and low side effects. During the long-term struggle against diseases, ancient Chinese doctors found that some unexpected materials, such as human or animal feces, could also effectively treat diseases. In China, the medical use of fecal matter (fresh fecal suspension or dry feces) has a long history. During the Eastern Jin

*Correspondence: fangang1111@163.com

${ }^{\dagger}$ Huan Du and Ting-ting Kuang contributed equally to this work

${ }^{2}$ School of Ethnic Medicine, Chengdu University of Traditional Chinese

Medicine, Chengdu 611137, China

Full list of author information is available at the end of the article dynasty (AD 300-400 years), "Zhou Hou Bei Ji Fang", a well-known monograph of traditional Chinese medicine (TCM) written by Hong Ge, recorded a case of treating patients with food poisoning or severe diarrhea by ingesting human fecal suspension (known as yellow soup or Huang-Long decoction) [1]. During the Tang dynasty, Yutuo Ningma Yundan Gongbu compiled a world-famous book of Tibetan medicine called "The Four Medical Tantras", which recorded that digestive diseases can be treated with the processed product of the feces of Sus scrofa (Hei-Bing-Pian in Chinese) [2]. Later, the "Compendium of Materia Medica" (a masterpiece of herbalism written by Shizhen Li during the Ming dynasty) described a series of prescriptions for treating diarrhea, rheumatism, jaundice, fever, and pain using fresh fecal suspension or dry feces [3]. In addition, "Jing Zhu Materia Medica" written by Danzeng 
Pengcuo Dimaer in the nineteenth century recorded that Hei-Bing-Pian and the dry feces of Gypaetus barbatus or Aegypius monachus (Jiu-Fen in Chinese) are commonly used to treat dyspepsia and gastric ulcer [4]. These records indicate that fecal medicines are widely used and occupy an important position in Chinese traditional medical systems.

In long-term clinical practice, Chinese doctors have accumulated unique experience in the use of fecal medicines. For example, the dry feces of Trogopterus xanthipes (Wu-Ling-Zhi in Chinese) is often used to treat blood stasis, swelling and aching due to traumatic injury [5]. Jiu-Fen is good at treating gastrointestinal diseases, such as dyspepsia, weak gastrointestinal function and gastric ulcer. Hei-Bing-Pian can treat diseases, such as indigestion, diarrhea and distending pain in the stomach [6]. These traditional medication experiences are undoubtedly valuable assets and can provide a reference for modern drug development. However, documents on the traditional use of fecal medicines are scattered and lack systematic collation.

In this review, we comprehensively collect and summarize the names, origins, and treated diseases of fecal medicines that have been used in some Chinese traditional medical systems, including TCM, Tibetan ethnic medicine (EM), Oroqen EM, Kazak EM, Uygur EM, Mongolian EM, Nu EM, Yao EM, Wa EM, Tujia EM, Korean EM, Jino EM, Hani EM, and Dai EM. In addition, we review the most frequently used fecal medicines in terms of their origins, traditional uses, chemical constituents, and pharmacological activities. Such information can provide a good reference for their development and utilization. These fecal medicines may be a valuable gift from Chinese traditional medicine to the world and has potential as drug candidates for the treatment of some chronic diseases, such as gastrointestinal diseases.

\section{Methods}

We have manually searched 31 related medicine monographs and drug standards, such as "Zhou Hou Bei Ji Fang", "Compendium of Materia Medica", "Jing Zhu Materia Medica", "Dictionary of Chinese Ethnic Medicine", "Drug Standards of Tibetan Medicine", "Lan Liu Li", "Pharmacopoeia of the People's Republic of China", and "Chinese Tibetan Materia Medica", to obtain the information about the names, origins, traditional uses, and treated diseases of fecal medicines. In addition, we have searched the online Chinese literature databases (i.e., Wan fang and CNKI) and international English databases (i.e., PubMed, ISI Web of Science and Google Scholar), using their vernacular or Latin names as keywords, to obtain their chemical constituents and biological effects.

\section{Results}

This review recorded 54 fecal medicines that have been used in 14 Chinese traditional medical systems. Their names, original species, medicinal forms, and treated diseases are presented in Tables 1 and 2. These 54 medicines mainly originate from the feces of 56 animals. Among medicinal forms used, dry feces is the most frequently used (66.67\%), followed by processed feces (29.63\%) and fresh fecal juice (3.70\%). In addition, we found that these 54 fecal medicines are mainly used to treat gastrointestinal (37.04\%), nervous system $(22.22 \%)$, skin (22.22\%), ophthalmic (18.52\%), and gynecological diseases (16.67\%).

\section{Fecal medicines used in the TCM system}

Traditional Chinese medicine is the most representative traditional medical system in China. It has a long history of more than 2500 years. In recent decades, TCM has attracted global attention due to its reliable therapeutic efficacy. Generally, TCM uses herbs, animals or minerals to treat diseases. In long-term clinical practices, animal feces have been found to be effective in treating some specific diseases under the guidance of TCM theory. As early as the Eastern Jin dynasty, human fecal juice (i.e., yellow soup) has been used by TCM practitioners to treat severe diarrhea [1]. At present, some fecal medicines are still used in the clinical practice of TCM. In the 2015 edition of Chinese Pharmacopoeia [7], 18 preparations have been found to contain fecal medicines (Table 5). For example, "Shi-Xiang-Zhi-Tong Powder" and "Tong-Jing Pills" contain Wu-Ling-Zhi, and "Huang-Lian-Yang-Gan Pills" contains Ye-Ming-Sha (dry feces of some kinds of bats).

In the present study, a bibliographic investigation of TCM monographs and drug standards revealed 14 kinds of fecal medicines that are commonly used in the TCM system. They mainly come from the feces of 22 animals and are widely used to treat dysmenorrhea, amenorrhea, abdominal mass, diarrhea, and blurred vision. Additional information on these 14 medicines is provided in Table 1. Wu-Ling-Zhi is the most representative fecal medicine in the TCM system (Fig. 1). Therefore, its traditional uses, chemical constituents and pharmacological activities are described in detail in the subsequent sections.

\section{The dry feces of Trogopterus xanthipes (Wu-Ling-Zhi in Chinese)}

Wu-Ling-Zhi (Fig. 1b), also named as Goreishi or Trogopterorum faeces, is one of the commonly used fecal 
Table 1 Fecal medicines used in the traditional Chinese medicine (TCM) system

\begin{tabular}{|c|c|c|c|c|c|}
\hline No. & Animal species & Medicinal form & Chinese name & Traditional uses (treated diseases) & Refs. \\
\hline 1 & Trogopterus xanthipes Milne-Edwards & Dry feces & Wu-Ling-Zhi & $\begin{array}{l}\text { Stabbing pain in chest and abdomen, dysmenorrhea, } \\
\text { amenorrhea, swelling and aching due to traumatic injury, } \\
\text { and snake bites }\end{array}$ & {$[5,8,52]$} \\
\hline 2 & Bombyx mori L. & Dry feces & Can-Sha & $\begin{array}{l}\text { Rheumatism, arthralgia, skin numbness, cold pain in waist } \\
\text { and legs, rubella itching, and headache }\end{array}$ & {$[3,52]$} \\
\hline \multirow[t]{4}{*}{3} & Vespertilio superans Thomas & \multirow[t]{4}{*}{ Dry feces } & \multirow[t]{4}{*}{ Ye-Ming-Sha } & \multirow{4}{*}{$\begin{array}{l}\text { Night blindness, swelling and pain in the eyes, infantile } \\
\text { malnutrition, scrofula, and malaria }\end{array}$} & \multirow[t]{4}{*}[5,53]{} \\
\hline & Rhinolophus ferrumequinum Schreber & & & & \\
\hline & Plecotus auritus L. & & & & \\
\hline & Hipposideros armiger Hodgson & & & & \\
\hline \multirow[t]{3}{*}{4} & Lepus mandschuricus Radde & \multirow[t]{3}{*}{ Dry feces } & \multirow[t]{3}{*}{ Wang-Yue-Sha } & \multirow{3}{*}{$\begin{array}{l}\text { Blurred vision, hemorrhoids and fistula, and infantile } \\
\text { malnutrition }\end{array}$} & \multirow[t]{3}{*}[52,54,55]{} \\
\hline & Lepus sinensis Gray & & & & \\
\hline & Lepus oiostolus Hodgson & & & & \\
\hline 5 & Gallus gallus domesticus Brisson & Dry feces & Ji-Shi-Bai & $\begin{array}{l}\text { Jaundice, gonorrhea, wandering arthritis, tetanus, spasm of } \\
\text { muscles and tendons, and diabetes }\end{array}$ & {$[3,56]$} \\
\hline \multirow[t]{2}{*}{6} & Rattus flavipectus Milne-Edwards & \multirow[t]{2}{*}{ Dry feces } & \multirow[t]{2}{*}{ Liang-Tou-Jian } & \multirow{2}{*}{$\begin{array}{l}\text { Fever due to typhoid, abdominal pain, stranguria with turbid } \\
\text { urine, amenorrhea, infantile malnutrition, mammary } \\
\text { abscess, and furuncle }\end{array}$} & \multirow[t]{2}{*}[56-58]{} \\
\hline & Rattus norvegicus Berkenhout & & & & \\
\hline 7 & Columba livia domestica $\mathrm{L}$. & Dry feces & Zuo-Pan-Long & Abdominal mass, scrofula and tetanus & {$[3,57]$} \\
\hline 8 & Physeter macrocephalus L. & Dry feces & Long-Xian-Xiang & $\begin{array}{l}\text { Coma due to stuffiness, abdominal pain, cough and dysp- } \\
\text { nea, and gonorrhea }\end{array}$ & {$[52,56]$} \\
\hline 9 & Passer montanus L. & Dry feces & Bai-Ding-Xiang & $\begin{array}{l}\text { Abdominal mass, carbuncle and furuncle, blurred vision, } \\
\text { pterygium, and dental caries }\end{array}$ & {$[55,56,58]$} \\
\hline 10 & Homo sapiens & Fresh fecal juice & $\begin{array}{l}\text { Yellow soup or Huang- } \\
\text { Long decoction }\end{array}$ & $\begin{array}{l}\text { Food poisoning, severe diarrhea, heat toxin, and uncon- } \\
\text { sciousness due to high fever }\end{array}$ & {$[1,3]$} \\
\hline 11 & Hirundo daurica $\mathrm{L}$. & Dry feces & Yan-Zi-Fen & Edema, malaria, insect poison, ulcer and sore & {$[3,56]$} \\
\hline 12 & Pavo muticus L. & Dry feces & Kong-Que-Fen & Excessive leucorrhea in women, dysuria and furuncle & {$[3,56]$} \\
\hline \multirow[t]{2}{*}{13} & Bos taurus domesticus Gmelin & \multirow{2}{*}{$\begin{array}{l}\text { Fresh fecal juice or } \\
\text { dry feces }\end{array}$} & \multirow[t]{2}{*}{ Niu-Fen } & \multirow{2}{*}{$\begin{array}{l}\text { Fresh fecal juice can cure jaundice caused by diabetes, beri- } \\
\text { beri, cholera, and dysuria; dry feces can treat malignant } \\
\text { sore, cervical lymph node and tuberculosis fistula }\end{array}$} & \multirow[t]{2}{*}[3,56]{} \\
\hline & Bubalus bubalis L. & & & & \\
\hline \multirow[t]{2}{*}{14} & Ochotona thibetana Milne-Edwards & \multirow[t]{2}{*}{ Dry feces } & \multirow[t]{2}{*}{ Cao-Ling-Zhi } & \multirow{2}{*}{$\begin{array}{l}\text { Irregular menstruation, stagnant abdominal pain, stomach } \\
\text { pain, traumatic injury, and blood stasis }\end{array}$} & \multirow[t]{2}{*}[56,57]{} \\
\hline & Ochotona erythrotis Buchner & & & & \\
\hline
\end{tabular}

medicines. It derives from the dry feces of Trogopterus xanthipes. Wu-Ling-Zhi was first recorded in the classic Chinese medicinal book "Kai Bao Ben Cao" compiled in the Song Dynasty [8]. Its traditional uses were described in several TCM monographs and drug standards. For example, "Ben Cao Jing Shu" recorded that Wu-Ling-Zhi had a good therapeutic effect on stabbing pain caused by blood stasis [9]. In addition, the Chinese Pharmacopoeia 1990 edition recorded that Wu-Ling-Zhi had good effects of promoting blood circulation, removing blood stasis and relieving pain, and was usually used to treat the stabbing pain in the chest and hypochondrium, dysmenorrhea, amenorrhea, swelling and aching due to traumatic injury, postpartum blood stasis, and snake bites.

So far, some chemical constituents categorized as terpenoids, flavonoids, lignans, sterols, and esters have been isolated from Wu-ling-zhi. The chemical structures of representative compounds are shown in Fig. 2. Numata et al. [10] found that the feces of T. xanthipes contain several cytotoxic triterpenes, namely, pomolic acid,

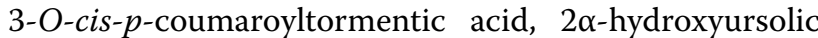
acid, and jacoumaric acid. Subsequently, they isolated three new ursane-type triterpenes (i.e., goreishic acids I, II and III) from the feces of T. xanthipes in 1990 [11]. In addition, 19 diterpenoids including three new isopimarane diterpenoids (trogopteroids $\mathrm{A}-\mathrm{C}$ ) and four new aromatic diterpenoids (trogopteroids D-G) were isolated from the feces of $T$. xanthipes [12]. Yang et al. [13] also isolated two new diterpenoids (wulingzhic acid A and wulingzhic acid B) from the feces of T. xanthipes. Additionally, the isolation and structural elucidation of flavonoids in Wu-Ling-Zhi were done by Yang et al. [14]. Seven flavonoids such as kaempferol 3-O- $\alpha-\mathrm{L}-\left(4^{\prime \prime} \mathrm{E}-p-\right.$ coumaroyl)-rhamnoside, hinokiflavone, afzelin, and quercitrin were found. In 2012, four new neolignans were obtained from the ethyl acetate fraction of methanol extract of Wu-Ling-Zhi [15]. Subsequently, they also isolated neolignans that had been reported before from its methanolic extract and named trogopterins A-C [16]. Moreover, Yang et al. [17] isolated four new fatty 
Table 2 Fecal medicines used in other traditional ethnic medicine (EM) systems in China

\begin{tabular}{|c|c|c|c|c|c|}
\hline No. & Animal species & Medicinal form & $\begin{array}{l}\text { Traditional medical } \\
\text { systems }\end{array}$ & Traditional uses (treated diseases) & Refs. \\
\hline 1 & $\begin{array}{l}\text { Gypaetus barbatus L. } \\
\text { Aegypius monachus L. }\end{array}$ & Dry feces & $\begin{array}{l}\text { Tibetan EM and mongo- } \\
\text { lian EM }\end{array}$ & $\begin{array}{l}\text { Dyspepsia, abdominal distension, intestinal tumor, } \\
\text { gastric ulcer, weak gastrointestinal function, sores and } \\
\text { carbuncles }\end{array}$ & {$[2,4,6]$} \\
\hline 2 & Sus scrofa L. & Processed feces & $\begin{array}{l}\text { Tibetan EM and mongo- } \\
\quad \text { lian EM }\end{array}$ & $\begin{array}{l}\text { Dyspepsia, biliary diseases, plague and distending pain } \\
\text { of stomach }\end{array}$ & {$[6,36,59]$} \\
\hline 3 & Sus scrofa domestica Brisson & Processed feces & Tibetan EM & Dyspepsia, plague and biliary tumor & {$[4,36,60]$} \\
\hline 4 & Petaurista xanthotis Milne-Edwards & Dry feces & Tibetan EM & Stomach pain, amenorrhea and dysmenorrhea & {$[59,60]$} \\
\hline \multirow[t]{3}{*}{5} & Pteromys volans $\mathrm{L}$. & Dry feces & Oroqen EM & Dysentery and diarrhea & {$[60]$} \\
\hline & & & Kazak EM & Metrorrhagia, amenorrhea, and snake bites (external use) & {$[60]$} \\
\hline & & & Uygur EM & $\begin{array}{l}\text { Eczema, itching, amenorrhea, dysmenorrhea, stomach } \\
\text { pain, and traumatic injury }\end{array}$ & {$[61]$} \\
\hline 6 & Riparia riparia L. & Processed feces & Tibetan EM & $\begin{array}{l}\text { Bloody dysentery, chronic diarrhea, women amenorrhea, } \\
\text { and hematuria }\end{array}$ & {$[59,60]$} \\
\hline 7 & Felis ocreata domestica Brisson & Processed feces & Tibetan EM & Manic psychosis or madness & {$[36,60]$} \\
\hline 8 & Upupa epops L. & Processed feces & Tibetan EM & Psychopathy & {$[4,59]$} \\
\hline 9 & Vulpes vulpes $\mathrm{L}$. & Dry feces & Tibetan EM & Psychopathy and epilepsy & {$[4,60]$} \\
\hline \multirow[t]{7}{*}{10} & Trogopterus xanthipes Milne-Edwards & Dry feces & Mongolian EM & Diarrhea, gout and itching & {$[62]$} \\
\hline & & & Nu EM & Cold, whooping cough and fever & {$[60]$} \\
\hline & & & Tibetan EM & Stomach pain, dysmenorrhea and amenorrhea & {$[59,60]$} \\
\hline & & & Tujia EM & $\begin{array}{l}\text { Blood stasis, furuncles, traumatic injury, dysmenorrhea, } \\
\text { and snake bites (external use) }\end{array}$ & {$[60]$} \\
\hline & & & Korean EM & $\begin{array}{l}\text { Stabbing pain in chest and abdomen, dysmenorrhea, } \\
\text { amenorrhea, swelling and aching due to traumatic } \\
\text { injury }\end{array}$ & {$[60]$} \\
\hline & & & Dai EM & $\begin{array}{l}\text { Amenorrhea, dysmenorrhea, pain due to blood stasis, and } \\
\text { snake bites (external use) }\end{array}$ & {$[60]$} \\
\hline & & & Yao EM & Dysmenorrhea, amenorrhea, and epilepsy & [63] \\
\hline \multirow[t]{3}{*}{11} & Pipistrellus abramus Temminck & Dry feces & Wa EM & Asthma, burn, night blindness, and infantile malnutrition & {$[60]$} \\
\hline & & & Tibetan EM & Epilepsy & {$[4,60]$} \\
\hline & & & Tujia EM & $\begin{array}{l}\text { Night blindness, cataract, infantile malnutrition, and } \\
\text { corneal nebula }\end{array}$ & {$[64]$} \\
\hline \multirow[t]{2}{*}{12} & Vespertilio superans Thomas & Dry feces & Korean EM & $\begin{array}{l}\text { Night blindness, intermittent fever, cataract, and under- } \\
\text { arm odor }\end{array}$ & {$[60]$} \\
\hline & & & Yao EM & $\begin{array}{l}\text { Night blindness, corneal nebula, infantile malnutrition, } \\
\text { and scrofula }\end{array}$ & {$[63]$} \\
\hline 13 & Plecotus kozlovi Bobrinski & Processed feces & Tibetan EM & Eye diseases, scrofula and infantile malnutrition & {$[60]$} \\
\hline 14 & Myotis mystacinus Kuhl & Processed feces & Tibetan EM & Psychosis and epilepsy & {$[60]$} \\
\hline 15 & Lepus capensis L. & Dry feces & Tibetan EM & $\begin{array}{l}\text { Blurred vision, hemorrhoids and fistula, and infantile } \\
\text { malnutrition }\end{array}$ & {$[4,59]$} \\
\hline 16 & Equus caballus orientalis Noack & Processed feces & Tibetan EM & Various parasitic diseases and vomiting & {$[65,66]$} \\
\hline \multirow[t]{3}{*}{17} & Gallus gallus domesticus Brisson & Dry feces & Korean EM & Jaundice, gonorrhea, tetanus, and diabetes & {$[60]$} \\
\hline & & & Tibetan EM & Eye diseases & {$[4,60]$} \\
\hline & & & Dai EM & Shoulder arthritis, tetanus and corneal scar & {$[60]$} \\
\hline 18 & Rattus rattus L. & Dry feces & Tibetan EM & Epilepsy & {$[59,60]$} \\
\hline 19 & Physeter macrocephalus L. & Dry feces & Uygur EM & Neurasthenia, memory loss and psychological impotence & {$[60]$} \\
\hline \multirow[t]{3}{*}{20} & Passer montanus L. & Dry feces & Jino EM & Manic psychosis or madness & {$[60]$} \\
\hline & & & Hani EM & Hernia & \\
\hline & & & Tibetan EM & Sores and furuncles (external use) & {$[59,60]$} \\
\hline 21 & Columba rupestris Pallas & Dry feces & Tibetan EM & Swelling and suppuration & {$[2,60]$} \\
\hline 22 & Pavo muticus L. & Processed feces & Tibetan EM & Inflammation & {$[4,36,59]$} \\
\hline 23 & Bos taurus domesticus Gmelin & Processed feces & Tibetan EM & Food poisoning, limbs pain, and spasm & {$[4,36,59]$} \\
\hline 24 & Canis lupus L. & Processed feces & $\begin{array}{l}\text { Tibetan EM and mongo- } \\
\text { lian EM }\end{array}$ & Psychopathy and swelling & {$[4,59]$} \\
\hline 25 & Tetraogallus tibetanus Gould & Dry feces & Tibetan EM & Various swelling & {$[2,36]$} \\
\hline 26 & Bubo bubo hemachalana Hume & Processed feces & Tibetan EM & Psychopathy and epilepsy & {$[4,59,67]$} \\
\hline
\end{tabular}


Table 2 (continued)

\begin{tabular}{|c|c|c|c|c|c|}
\hline No. & Animal species & Medicinal form & $\begin{array}{l}\text { Traditional medical } \\
\text { systems }\end{array}$ & Traditional uses (treated diseases) & Refs. \\
\hline 27 & Pica pica L. & Dry feces & Tibetan EM & Skin diseases, such as sores and furuncles & {$[59,60]$} \\
\hline 28 & Streptopelia orientalis Latham & Dry feces & Uygur EM & Purulent secretion of the ear; Pain caused by ear diseases & {$[61]$} \\
\hline 29 & Corvus corax L. & Processed feces & Tibetan EM & Bromhidrosis, epilepsy, cough, and psychopathy & {$[59,60]$} \\
\hline 30 & Canis lupus familiaris L. & Processed feces & Tibetan EM & $\begin{array}{l}\text { Psychopathy and swelling; Syphilis, psoriasis and anthrac- } \\
\text { nose (external use) }\end{array}$ & {$[4,59,60]$} \\
\hline 31 & Elephas maximus L. & Dry feces & Dai EM & Ophthalmitis & {$[60]$} \\
\hline 32 & Equus asinus L. & Processed feces & Tibetan EM & Sores and furuncles (external use) and rabies & {$[4,59]$} \\
\hline 33 & Phalacrocorax carbo L. & Dry feces & Korean EM & Pigmented naevus (external use) & {$[60]$} \\
\hline 34 & Buteo hemilasius Temminck et Schlegel & Dry feces & Tibetan EM & Sores and furuncles (external use) & {$[4,59]$} \\
\hline 35 & Macaca mulatta Zimmermann & Dry feces & Tibetan EM & Inflammation, swelling and dysentery & {$[59,60]$} \\
\hline 36 & Ovis aries $\mathrm{L}$. & Dry feces & Tibetan EM & $\begin{array}{l}\text { "Huang-Shui" disease in arms and legs (external fumiga- } \\
\text { tion) }\end{array}$ & {$[59,60]$} \\
\hline \multirow[t]{2}{*}{37} & Capra hircus L. & Dry feces & Tibetan EM & $\begin{array}{l}\text { Heat toxin syndrome, nervous system diseases and } \\
\text { leprosy }\end{array}$ & {$[4,60]$} \\
\hline & & & Korean EM & Child dysentery, borborygmus and convulsive epilepsy & {$[60]$} \\
\hline 38 & Tetrao urogalloides Middendorf & Dry feces & Tibetan EM & Psychopathy and swelling & [4] \\
\hline 39 & Lutra lutra L. & Processed feces & Tibetan EM & Uterine diseases & {$[4,60]$} \\
\hline 40 & Moschus sifanicus Przewalski & Dry feces & Tibetan EM & Limb numbness, paralysis and blood stasis & {$[4,36,59]$} \\
\hline
\end{tabular}

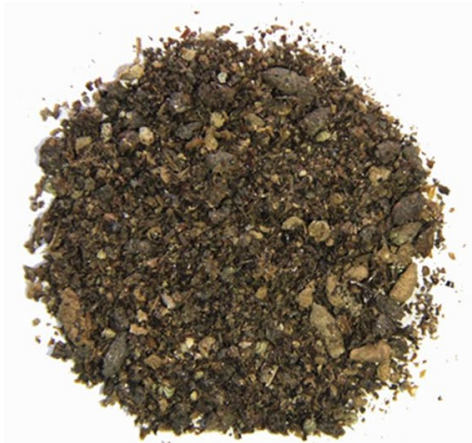

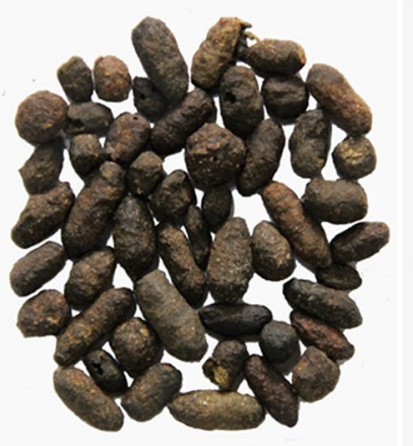

b

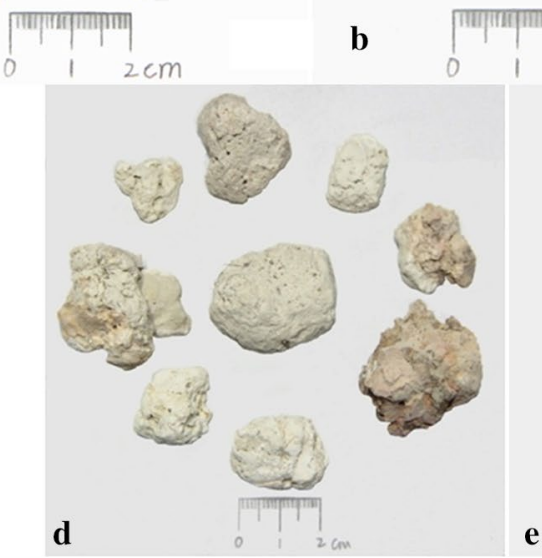

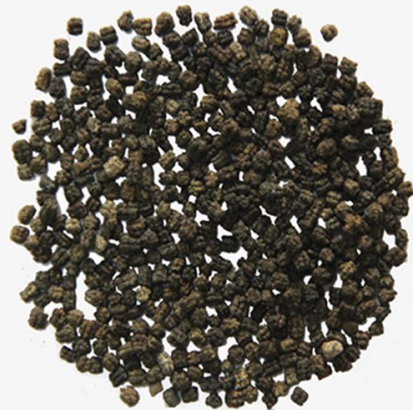

c

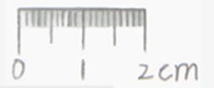

a

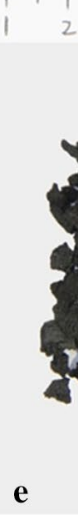

61]

$[59,60]$

4,59

$[59,60]$

60]

60

$[4,60]$

, 36, 59]

Fig. 1 The commonly used fecal medicines in traditional medical system of China (a Ye-Ming-Sha; b Wu-Ling-Zhi; c Can-Sha; d Jiu-Fen; e Hei-Bing-Pian) 


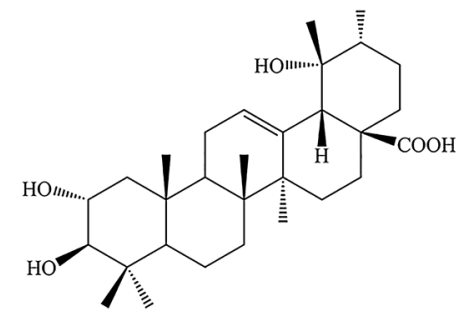

Tormentic acid<smiles>CCO[C@@]12C=CC3=C(C)C(=O)CC[C@]3(C)C1CCC(C)(C)C2</smiles>

Trogopteroids A<smiles>C[C@]1(O)CC[C@H]2C(=CCC3[C@](C)(O)[C@@H](O)CC[C@]32C)C1</smiles>

Wulingzhic acid<smiles>CC1CC[C@]2(O)CC[C@]3(C)C(=CCC4C3(C)CCC3C(C)(C)[C@H](O)CC[C@@]34C)[C@@]2(C)C1C</smiles>

Ursolic acid

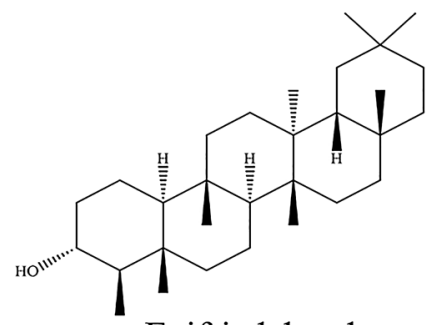

Epifriedelanol<smiles>C=C[C@]1(C)CC[C@@H]2C(C)(C)CCC[C@@]2(C)C1</smiles>

Akhdardiol<smiles>CC(C)c1cc2c(cc1O)[C@]1(C)CCCC(C)(C)[C@@]1(C)CC2</smiles>

Ferruginol<smiles>O=c1cc(-c2ccc(Oc3c(O)cc4oc(-c5ccc(O)cc5)cc(=O)c4c3O)cc2)oc2cc(O)cc(O)c12</smiles>

Hinokiflavone<smiles></smiles>

Quercitrin<smiles>OC[C@H]1Cc2cc(O)ccc2[C@H](CO)[C@@H]1c1cccc(O)c1</smiles>

Trogopterins C<smiles>O=C(O)c1ccc(O)c(O)c1</smiles>

Protocatechuic acid

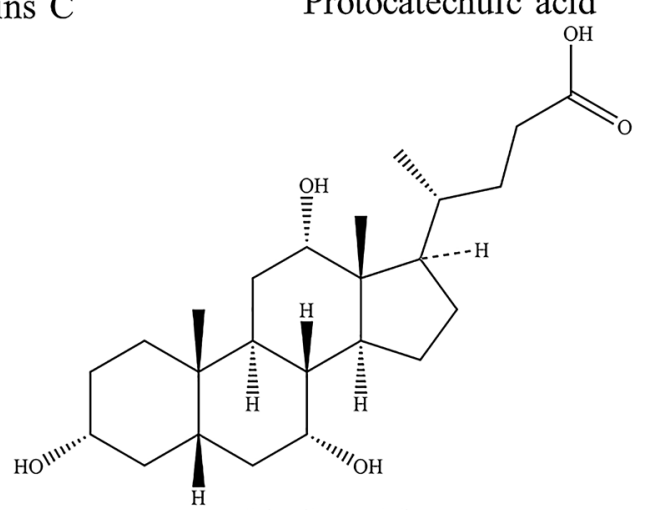

Cholic acid

Fig. 2 Chemical structures of representative compounds isolated from Wu-Ling-Zhi and Hei-Bing-Pian

acid esters from the feces of T. xanthipes. Currently, it was reported that dihydrositosterol, epifriedelanol, 5-methoxy-7-hydroxycoumarin, $\beta$-sitosterol, ursolic acid, protocatechuic acid, and daucosterol were also isolated from Wu-Ling-Zhi [18, 19]. Moreover, some volatile compounds identified by capillary gas chromatography 


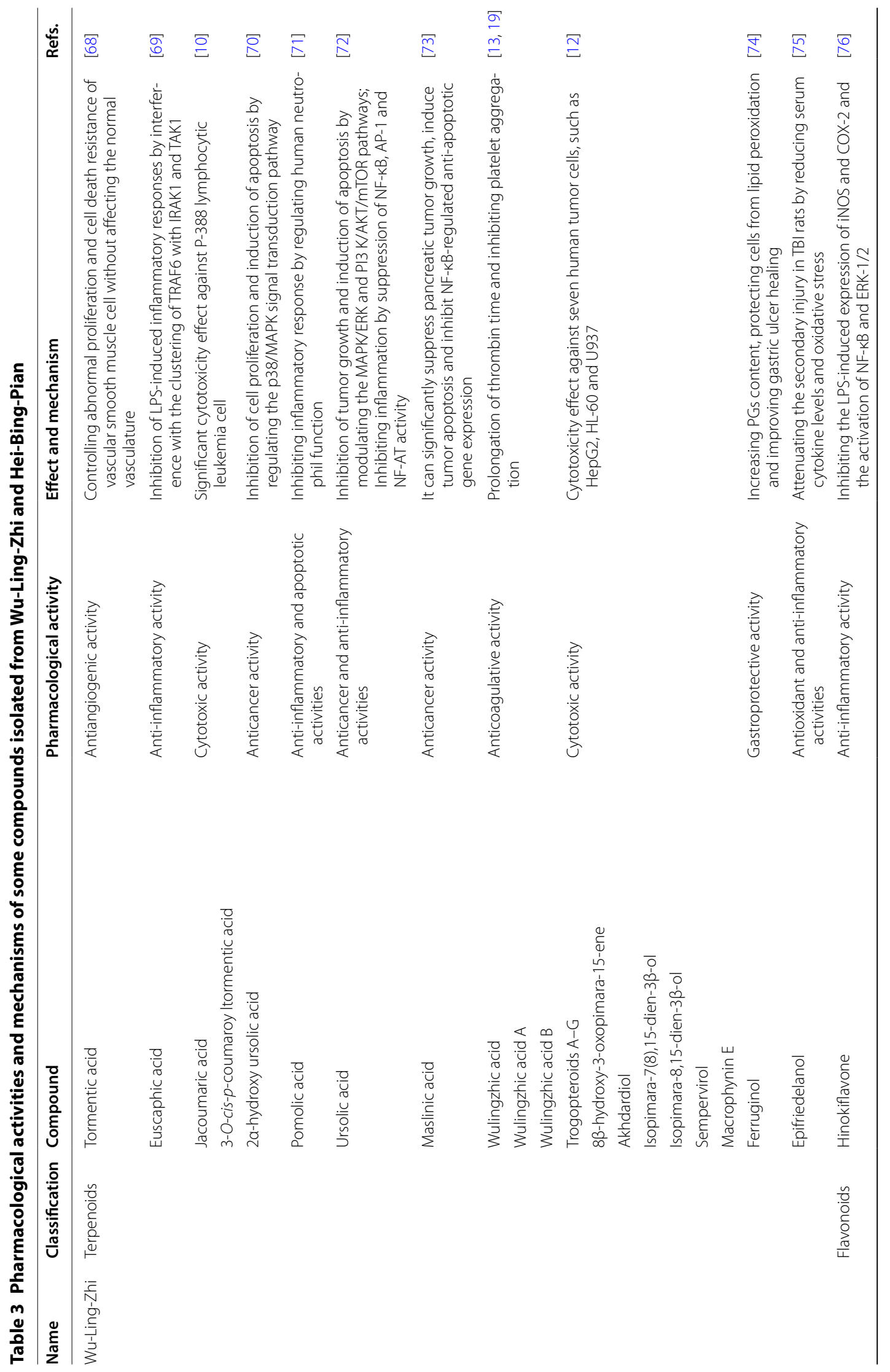




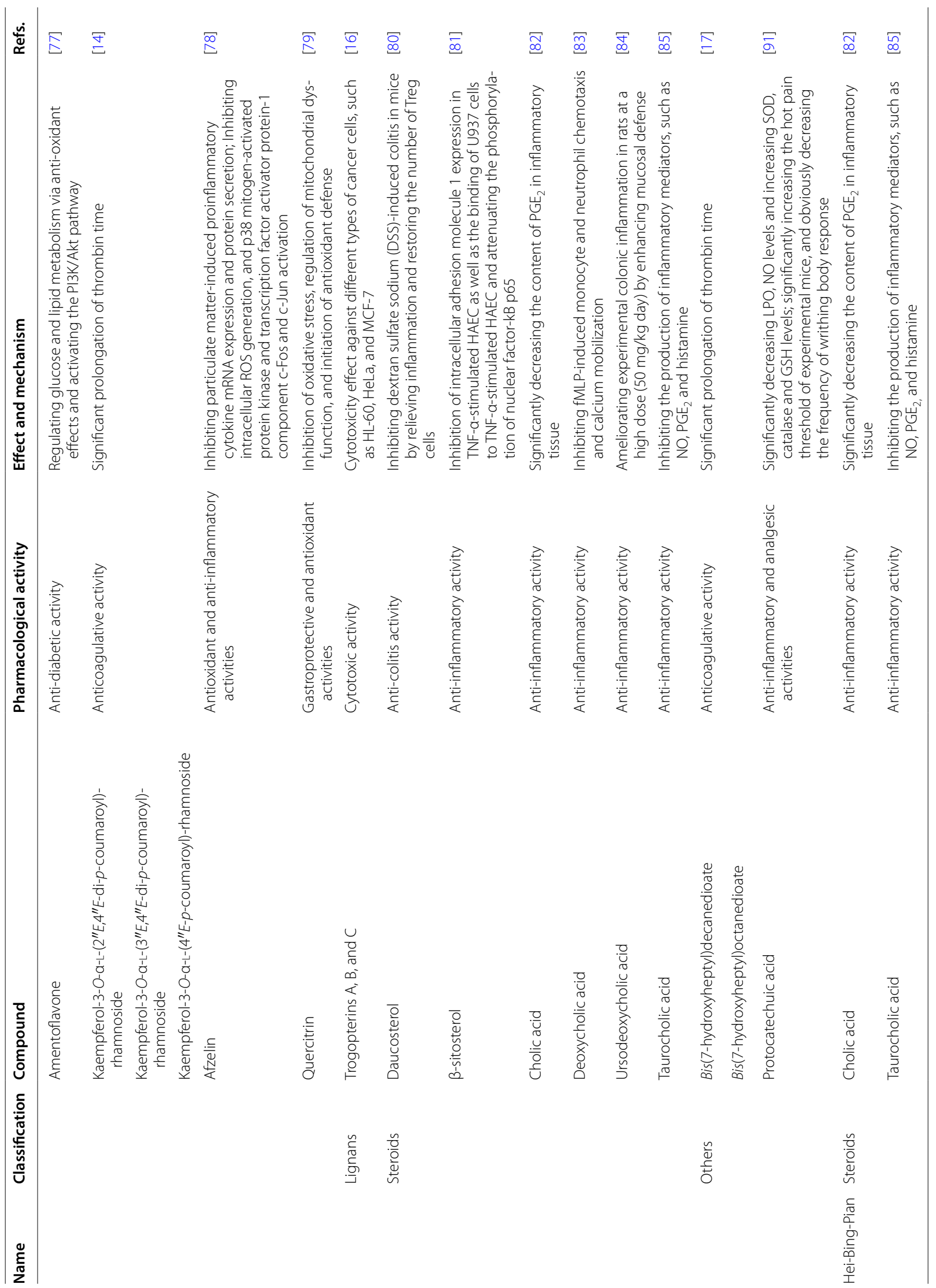




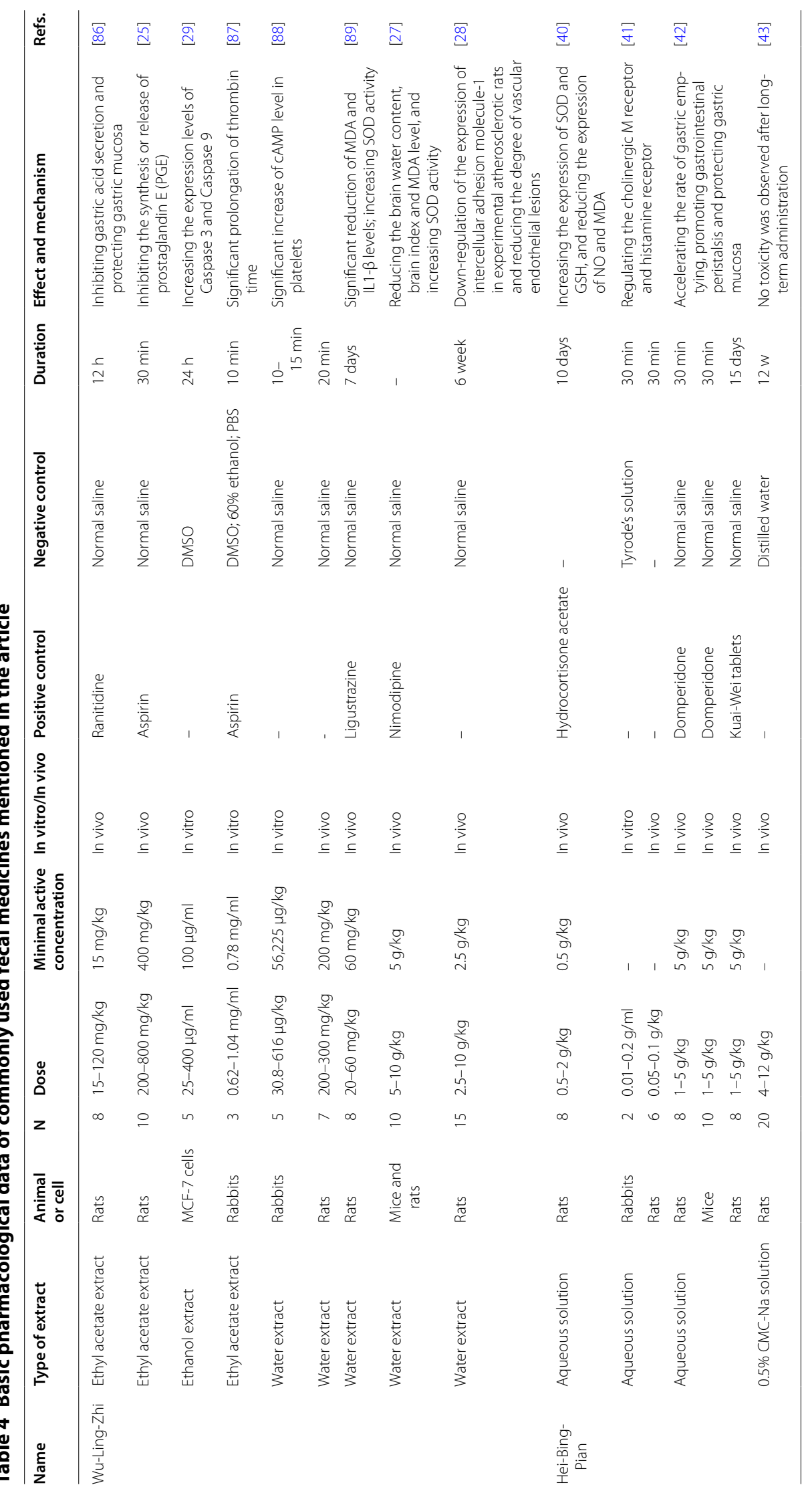


combined mass spectrometry were also found in Wuling-zhi, such as dodecanoic acid, alpha-cedrol, tetradecanoic acid, and benzaldehyde [20].

At present, there are some studies involving the quality control of Wu-Ling-Zhi. Yerigui et al. [21] quantified five bile acids (i.e., cholic acid, deoxycholic acid, lithocholic acid, ursodeoxycholic acid, and taurocholic acid) in WuLing-Zhi by using ultra high-performance liquid chromatography-mass spectrometry. Jiao et al. [22] established a thin layer chromatography (TLC) method for qualitative identification of Wu-Ling-Zhi, and developed a high performance liquid chromatography (HPLC) method to simultaneously quantify three active ingredients (protocatechuic acid, hinokiflavone and amentoflavone) in WuLing-Zhi. Recently, Chen et al. also established the quality standard of Wu-Ling-Zhi. They qualitatively and quantitatively analyzed quercetin, kaempferol and amentoflavone in Wu-Ling-Zhi by TLC and HPLC, respectively [23]. These results can provide important reference for the quality control of Wu-Ling-Zhi.

Moreover, it is worth pointing out that extracts or chemical constituents obtained from the Wu-Ling-Zhi have been proved to possess a wide spectrum of pharmacological activities, such as anti-inflammatory, anticerebral ischemia, anti-gastric ulcer, and antithrombin effects. The basic pharmacological data of Wu-Ling-Zhi extracts and some isolated compounds are shown in Tables 3 and 4. Kim et al. [24] reported that Wu-LingZhi extract could reduce lipopolysaccharide-induced $\mathrm{NO}$ and cytokines production. Wang et al. [25] found that the ethyl acetate extract of Wu-Ling-Zhi showed obvious inhibitory effects on xylene-induced ear swelling in mice and carrageenan-induced paw swelling in rats $(400 \mathrm{mg} / \mathrm{kg}$, ip), and it could also significantly inhibit the proliferation of granulation tissue in mice $(800 \mathrm{mg} / \mathrm{kg}$, ip). These findings indicated that $\mathrm{Wu}-$ Ling-Zhi has obvious anti-inflammatory effect. Furthermore, the ethyl acetate extract of Wu-Ling-Zhi was also found to be able to protect gastric mucosa and prevent experimental gastric ulcer by inhibiting gastric acid secretion [26]. It was reported that the aqueous extract of Wu-Ling-Zhi could significantly prolong the survival time of mice with incomplete cerebral ischemia, reduce the brain water content, brain index and malondialdehyde (MDA) level, and increase superoxide dismutase (SOD) activity in rats, indicating that $\mathrm{Wu}$-Ling-Zhi has good protective effect against cerebral ischemia [27]. Moreover, the aqueous extract of Wu-Ling-Zhi could down-regulate the expression of intercellular adhesion molecule-1 in experimental atherosclerotic rats and reduce the degree of vascular endothelial lesions, which may account for the anti-arteriosclerosis inflammatory effects of Wu-Ling-Zhi [28].
Currently, several compounds isolated from $\mathrm{Wu}-$ Ling-Zhi, such as $3-O-\alpha-\mathrm{L}-\left(2^{\prime \prime} E, 4^{\prime \prime} E\right.$-di-p-coumaroyl)rhamnoside, bis(7-hydroxyheptyl) decanedioate and bis(7-hydroxyheptyl) octanedioate, were found to have significant antithrombin activity [14, 17]. Besides, a recent study showed that Wu-Ling-Zhi could trigger caspase dependent apoptosis in breast cancer cells (MCF-7 cells) [29].

\section{Fecal medicines used in other traditional ethnic medicine systems in China}

In addition to the TCM system, there are other traditional medical systems in China, such as Tibetan, Mongolian, Uygur, Tujia, Kazak, Yao, Korean, and Dai ethnic medicines. These ethnic medical systems have their own unique theories in the use of natural medicines. Therefore, it is also important to collect information about fecal medicines from these ethnic medical systems.

Traditional Tibetan medicine (TTM) is a representative ethnic medicine in China, and it has a unique fundamental theory, namely three elements theory consisting of "rLung", "mKhris-pa" and "Badkan" [30]. In TTM system, the use of fecal medicines has a long history. The earliest Tibetan medicine monograph that recorded fecal medicines is "The Four Medical Tantras" [2]. Later, in the seventeenth century, famous "Tibetan Medical Thangka of The Four Medical Tantras" [31] was published by Sdesrid-sangs-rgyas-rgya-mtsho, which vividly depicted some commonly used fecal medicines in the form of wall chart (Fig. 3).

In this study, we found that the feces of 41 animals were used as medicines for the treatment of various diseases in 13 ethnic medical systems. More information on these medicines is provided in Table 2. Among them, the dry feces of Gypaetus barbatus or Aegypius monachus and the processed product of the feces of Sus scrofa are representative fecal medicines in Chinese ethnic medicine systems. Their traditional uses, chemical constituents and pharmacological activities have been described in detail in the following sections.

\section{The dry feces of Gypaetus barbatus or Aegypius monachus (Jiu-Fen in Chinese)}

The dry feces of G. barbatus or A. monachus, known as Jiu-Fen in Chinese, is a commonly used Tibetan medicine (Fig. 1d). It has the functions of strengthening stomach and promoting digestion. Jiu-Fen is used in the traditional Tibetan system of medicine for the treatment of dyspepsia, gastrointestinal dysfunction, gastric ulcer, and intestinal cancer in the past few decades $[4,6]$. In addition, the "Jing Zhu Materia Medica" recorded that Jiu-Fen can be used to treat mental illness [4]. Nowadays, Jiu-Fen is frequently used in the clinical practice of 


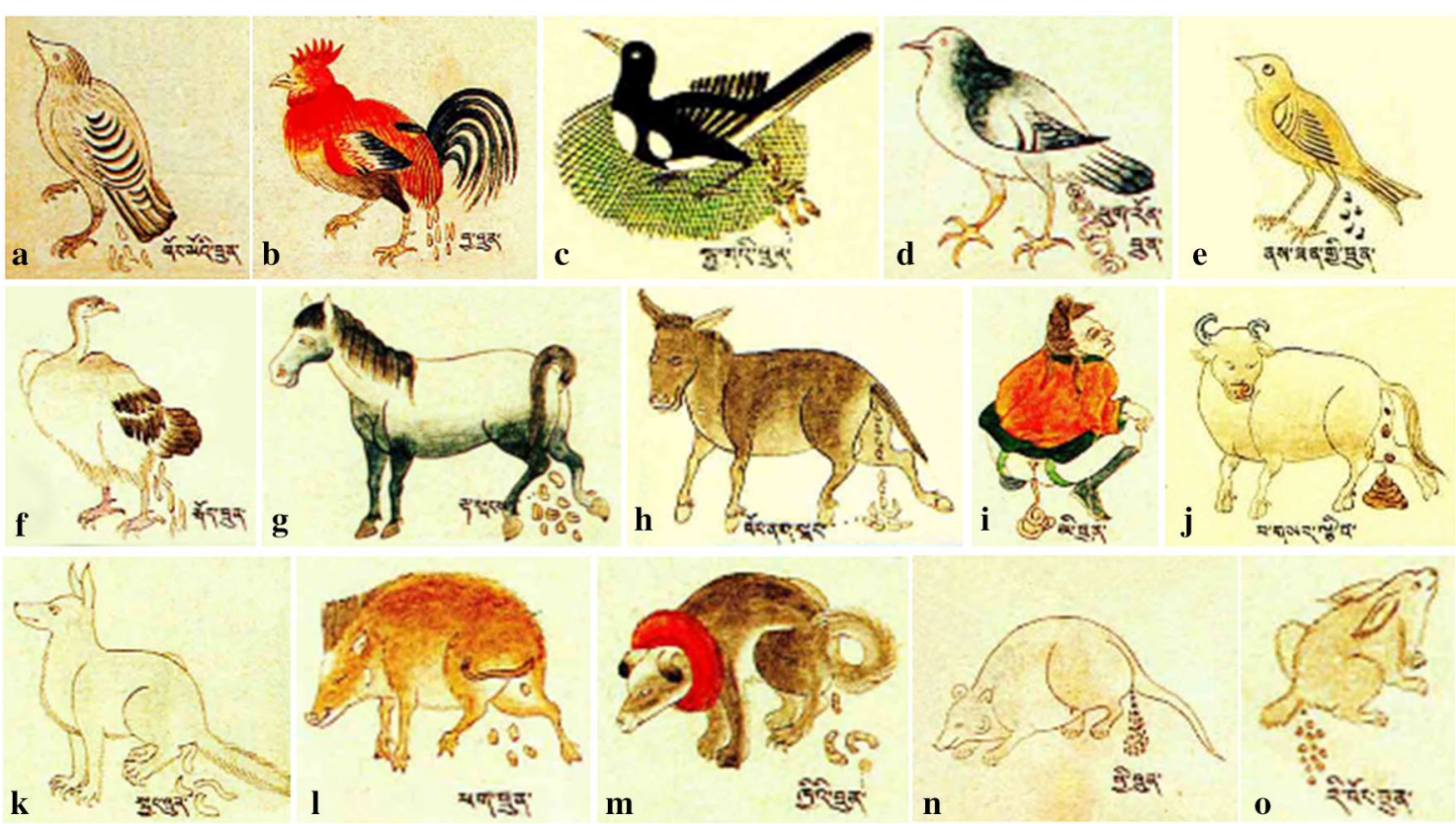

Fig. 3 The Tibetan medical Thangka of "The Four Medical Tantras" vividly depicts some feces medicines and their origin animals (a Tetrao urogallus; b Gallus gallus domesticus; c Pica pica; $\mathbf{d}$ Columba livia domestica; e Passer montanus; $\mathbf{f}$ Aegypius monachus; $\mathbf{g}$ Equus caballus orientalis; $\mathbf{h}$ Equus asinus; $\mathbf{i}$ Homo sapiens; $\mathbf{j}$ Bos taurus domesticus; $\mathbf{k}$ Canis lupus; I Sus scrofa; $\mathbf{m}$ Canis lupus familiaris; $\mathbf{n}$ Rattus rattus; o Lepus oiostolus)

TTM by combining other herbs. According to our statistics, there are 32 preparations containing Jiu-Fen in some monographs and drug standards of Tibetan medicine [6,32-35]. The representative prescriptions include "Shi-Wei-Jiu-Fen Powder", "Er-Shi-Jiu-Wei-Neng-Xiao Powder" and "Jian-Hua-Mu-Xiang Pills" (Table 5). The "Tibetan Medicine Standards" recorded that "Shi-WeiJiu-Fen Powder" can strengthen stomach and promote digestion [6]. Consequently, it is usually used to treat gastrointestinal diseases such as dyspepsia.

The use of Jiu-Fen in the traditional Tibetan system of medicine has a long history, but modern research on the chemical composition, quality control and pharmacodynamic evaluation of Jiu-Fen has not yet been carried out. Therefore, further studies are needed to prove its medicinal values in gastrointestinal diseases treatment, identify active compounds and elucidate the underlying mechanisms with the help of modern chemistry and pharmacology methods.

\section{The processed product of the feces of Sus scrofa (Hei-Bing-Pian in Chinese)}

The processed product of the feces of Sus scrofa (wild boar), known as Hei-Bing-Pian (Chinese name), is a widely used Tibetan and Mongolian medicine in China (Fig. 1e). Its processing method was recorded in the "Chinese Materia Medica for Tibetan Medicine": firstly, the dry feces of Sus scrofa is put into a ceramic jar, and yellow mud (adding a small amount of salt) is used to seal the ceramic jar. Secondly, the ceramic jar is calcined with fire until it turns gray outside. Then, the black matter is taken out from the ceramic jar, which is Hei-Bing-Pian [36]. In traditional Tibetan system of medicine, Hei-Bing-Pian is described as pungent in flavor and hot in nature. It is commonly used for the treatment of dyspepsia, gallbladder diseases, stomachache, and plague [6]. According to our statistics, there are 14 Tibetan medicine preparations containing Hei-Bing-Pian in official drug standards. The representative prescriptions include "Shi-Wei-Hei-BingPian Powder", "Shi-Yi-Wei-Jin-Se Pills" and "Shi-Wu-WeiZhi-Xie-Mu Powder" (Table 5). The "Drug Standards of Tibetan Medicines" recorded that "Shi-Wei-Hei-BingPian Pills" is usually used to treat stomach and gallbladder diseases, such as dyspepsia, anorexia, jaundice, gallstones and nausea [35].

It has been reported that Hei-Bing-Pian contains a variety of inorganic elements, such as $\mathrm{Fe}, \mathrm{Ca}, \mathrm{Zn}, \mathrm{K}, \mathrm{Cu}, \mathrm{Mn}$, $\mathrm{Co}, \mathrm{Ti}$, and $\mathrm{Mg}$. At present, the contents of these elements in Hei-Bing-Pian have been determined by using atomic absorption spectrometry or spectrophotometry [37, 38]. The elements with high levels are Ca $(18,570 \mu \mathrm{g} / \mathrm{g}), \mathrm{K}$ $(11,625 \mu \mathrm{g} / \mathrm{g}), \mathrm{Mg}(9975 \mu \mathrm{g} / \mathrm{g})$, and Fe $(7800 \mu \mathrm{g} / \mathrm{g})$. Furthermore, two bile acids (i.e., cholic acid and taurocholic acid) were detected and quantified in Hei-Bing-Pian by 
Table 5 Representative prescriptions containing fecal medicines recorded in official drug standards

\begin{tabular}{|c|c|c|c|c|c|}
\hline Fecal medicine & $\begin{array}{l}\text { Traditional } \\
\text { medical } \\
\text { system }\end{array}$ & $\begin{array}{l}\text { The number } \\
\text { of preparations }\end{array}$ & The name of prescriptions & Drug standard & Refs. \\
\hline Wu-Ling-Zhi & TCM & 15 & $\begin{array}{l}\text { Shi-Xiang-Zhi-Tong Pills; Tong-Jing Pills; Shao-Fu-Zhu- } \\
\text { Yu Pills; Xiao-Jin Pills; Shi-Er-Wei-Yi-Shou Powder; } \\
\text { Er-Shi-Wu-Wei-Song-Shi Pills; Qi-Wei-Tie-Xie Pills; } \\
\text { Jiu-Qi-Niao-Tong Pills; Ping-Xiao Pills; Hua-Zheng- } \\
\text { Hui-Sheng Tablets; Feng-Liao-Xing-Feng-Shi-Die-Da } \\
\text { Wine; Yang-He-Jie-Ning Plaster; Tong-Jing-Bao } \\
\text { Granules; Jie-Bai Pills; Bing-Lang-Si-Xiao Pills }\end{array}$ & $\begin{array}{l}\text { Chinese Pharmacopoeia, } \\
\text { 2015ed }\end{array}$ & {$[7]$} \\
\hline Can-Sha & TCM & 2 & $\begin{array}{l}\text { Shu-Jing-Huo-Luo Wine; Feng-Liao-Xing-Feng-Shi-Die- } \\
\text { Da Wine }\end{array}$ & $\begin{array}{l}\text { Chinese Pharmacopoeia, } \\
\text { 2015ed }\end{array}$ & {$[7]$} \\
\hline Ye-Ming-Sha & TCM & 1 & Huang-Lian-Yang-Gan Pills & $\begin{array}{l}\text { Chinese Pharmacopoeia, } \\
\text { 2015ed }\end{array}$ & {$[7]$} \\
\hline Jiu-Fen & Tibetan EM & 12 & $\begin{array}{l}\text { Shi-Wei-Jiu-Fen Powder; Er-Shi-Jiu-Wei-Neng-Xiao Pow- } \\
\text { der; Jian-Hua-Mu-Xiang Pills; Shi-San-Wei-Mu-Xiang } \\
\text { Pills; Shi-San-Wei-Shi-Liu Pills; De-Ma-Shi-San-Wei- } \\
\text { Shi-Liu Pills; Shi-San-Wei-Mu-Xiang Powder; Jia-Wei- } \\
\text { Bai-Yao Pills; Qu-Hui Pills; Qu-Han-Quan-Lü Powder; } \\
\text { Song-Shi-Da-Peng Pills; Shi-San-Wei-Qing-Lan Pills }\end{array}$ & $\begin{array}{l}\text { Drug Standards of Tibetan } \\
\text { Medicines; Tibetan Medicine } \\
\text { Standards }\end{array}$ & {$[6,35]$} \\
\hline Hei-Bing-Pian & Tibetan EM & 14 & $\begin{array}{l}\text { Shi-Wei-Hei-Bing-Pian Powder; Shi-Yi-Wei-Jin-Se Pills; } \\
\text { Shi-Wu-Wei-Zhi-Xie-Mu Powder; Gan-Lu-Ling Pills; } \\
\text { Er-shi-Si-Wei-A-Wei Powder; Shi-Yi-Wei-He-Zi Powder; } \\
\text { Shi-San-Wei-Di-Da Powder; Niu-Huang-Qing-Peng } \\
\text { Pills; He-Zi-Neng-Xiao Pills; He-Zi-Qing Peng-Pills; } \\
\text { Jin-Se-Di-Da Pills; Er-shi-Jiu-Wei-Qiang-Huo Powder; } \\
\text { Shi-San-Wei-Shu-Tu-Qing-Peng Powder; Shi-Yi-Wei- } \\
\text { Jin-Se Powder }\end{array}$ & $\begin{array}{l}\text { Drug Standards of Tibetan } \\
\text { Medicines; Tibetan Medicine } \\
\text { Standards }\end{array}$ & {$[6,35]$} \\
\hline Wu-Ling-Zhi & Mongolian EM & 23 & $\begin{array}{l}\text { Yun-Xiang-Shi-Wu-Wei Pills; Zhi-Li-Shi-Wei-Hei Pills; } \\
\text { Niu-Huang-Shi-San-Wei Pills; Wen-Guan-Mu-Shi-Wei } \\
\text { Powder; Ji-Xiang-An-Kun Pills; Li-Gan-He-Wei Pills; } \\
\text { He-Zi-Wu-Wei Capsules; Bu-Sheng-Jian-Wei-Er-Shi-Yi } \\
\text { Pills; Feng-Xiang-Zhi-Shi-Wei Pills; Cao-Guo-Jian-Pi } \\
\text { Pills; Ha-Dun-Hai-Lu-Mu-Le-Shi-San-Wei Pills; Ha- } \\
\text { Dun-Hai-Lu-Mu-Le-Jiu-Wei Pills; Jian-Wei-Shi-Wei Pills; } \\
\text { Jian-Pi-Wu-Wei-Pills; Qing-Gan-Qi-Wei Powder;Tiao- } \\
\text { Yuan-Da-Bu-Er-Shi-Wu-Wei Decoction; Ju-Hua-Qi-Wei } \\
\text { Capsules; Qing-Gan-Jiu-Wei Powder; Qing-Shen-Re- } \\
\text { Shi-Wei Powder; Qing-Wen-Shi-Er-Wei Pills; Qing- } \\
\text { Wen-Zhi-Tong-Shi-Si-Wei Pills; Qing-Wen-Li-Dan-Shi- } \\
\text { San-Wei Pills; Xi-Hong-Hua-Shi-Liu-Wei Powder }\end{array}$ & $\begin{array}{l}\text { Drug Standards of Mongolian } \\
\text { Medicines }\end{array}$ & {$[90]$} \\
\hline Hei-Bing-Pian & Mongolian EM & 7 & $\begin{array}{l}\text { Zhi-Li-Shi-Wu-Wei Pills; He-Zi-Wu-Wei Capsules; } \\
\text { A-Na-Ri-Ba-Wei Powder; Ha-Ri-Shi-Er-Wei Powder; } \\
\text { Ha-Dun-Hai-Lu-Mu-Le-Shi-San-Wei Pills; Qing-Gan-Er- } \\
\text { Shi-Qi-Wei Pills; Shi-Wei-Hei-Bing-Pian Powder }\end{array}$ & $\begin{array}{l}\text { Drug Standards of Mongolian } \\
\text { Medicines }\end{array}$ & [90] \\
\hline Ye-Ming-Sha & Mongolian EM & 1 & Ming-Mu-Shi-Liu Pills & $\begin{array}{l}\text { Drug Standards of Mongolian } \\
\text { Medicines }\end{array}$ & {$[90]$} \\
\hline Long-Xian-Xiang & Uygur EM & 1 & Yi-Mu-Sa-Ke Tablets & $\begin{array}{l}\text { Drug Standards of Uygur } \\
\text { Medicines }\end{array}$ & {$[92]$} \\
\hline
\end{tabular}

using ultra high-performance liquid chromatographymass spectrometry method [21]. Besides, Chang et al. [39] developed a spectrophotometric method to determine the absorption force of Hei-Bing-Pian on tartrazine, and used this adsorption force as an indicator to control the quality of Hei-Bing-Pian.

Modern pharmacological study has demonstrated that Hei-Bing-Pian can prevent mucosal damage caused by experimental colitis in rats. Compared with the model group, the high and low doses of Hei-Bing-Pian can significantly reduce the damage of colonic mucosa congestion, hyperplasia and ulcer $(p<0.05)$, and significantly increase the levels of superoxide dismutase (SOD) and glutathione (GSH) [40]. Cai et al. [41] reported the effect of Hei-BingPian on the intestinal smooth muscle function of animals. It was found that Hei-Bing-Pian had no obvious effect on normal isolated ileum, and could not antagonize the inhibitory effect of atropine, adrenaline and promethazine 
Table 6 Similarities and differences of fecal medicines related to treated diseases in Chinese traditional medical systems

\begin{tabular}{|c|c|c|c|c|c|}
\hline Name & $\begin{array}{l}\text { Traditional } \\
\text { medical } \\
\text { system }\end{array}$ & Original species & Identical indications & Different indications & Refs. \\
\hline \multirow[t]{8}{*}{ Wu-Ling-Zhi } & TCM & $\begin{array}{l}\text { Trogopterus } \\
\text { xanthipes Milne- } \\
\text { Edwards }\end{array}$ & Amenorrhea and dysmenorrhea & $\begin{array}{l}\text { Stabbing pain in the chest and abdomen, swell- } \\
\text { ing and aching due to traumatic injury, and } \\
\text { snake bites (external use) }\end{array}$ & {$[5,8,52]$} \\
\hline & Tibetan EM & & & Stomachache & {$[59,60]$} \\
\hline & Korean EM & & & Stabbing pain in chest and abdomen & {$[60]$} \\
\hline & Dai EM & & & Snake bites (external use) & {$[60]$} \\
\hline & Yao EM & & & Epilepsy & {$[63]$} \\
\hline & Tujia EM & & & $\begin{array}{l}\text { Swelling and aching due to traumatic injury, and } \\
\text { snake bites (external use) }\end{array}$ & {$[60]$} \\
\hline & Nu EM & & - & Cold, whooping cough and fever & {$[60]$} \\
\hline & Mongolian EM & & - & Diarrhea, gout and itching & {$[62]$} \\
\hline Hei-Bing-Pian & $\begin{array}{l}\text { Tibetan EM } \\
\text { Mongolian EM }\end{array}$ & Sus scrofa L. & $\begin{array}{l}\text { Dyspepsia, biliary diseases, plague } \\
\text { and distending pain in the } \\
\text { stomach }\end{array}$ & - & {$[6,36,59]$} \\
\hline
\end{tabular}

on isolated ileum smooth muscle. However, it could significantly inhibit histamine-induced ileal smooth muscle excitation, and the inhibition rate was $25 \%$. Moreover, in vivo studies showed that Hei-Bing-Pian could inhibit the contraction effect of pilocarpine on ileal smooth muscle. These results indicate that the effect of Hei-Bing-Pian on intestinal smooth muscle is related to the cholinergic $\mathrm{M}$ receptor and histamine receptor. Bai et al. [42] found that Hei-Bing-Pian could significantly accelerate gastric emptying in rats and promote the propulsive speed of activated carbon in the small intestine of mice. Moreover, the high dose of Hei-Bing-Pian could significantly promote the healing of chronic gastritis caused by acetic acid, and had obvious protective effect on gastric mucosal injury induced by cold stress. Besides, in order to make better use of Hei-Bing-Pian, its long-term toxic effects have been studied by Li et al. The results showed that, after 12 weeks of administration of Hei-Bing-Pian, there were no significant changes in body weight, blood biochemical parameters, histopathology, and several organ indexes (e.g., heart, liver, spleen, kidney, and thymus) in rats, compared with the control group, which indicated that Hei-Bing-Pian has no potential toxicity [43]. The basic pharmacological data of Hei-Bing-Pian and its ingredients are shown in Tables 3 and 4.

\section{Similarities and differences of fecal medicines related to treated diseases in Chinese traditional medical systems} Every traditional medical system in China has its own unique theory or medication experience. Therefore, the same fecal medicines are used in different medical systems, and their therapeutic uses may be different. A detailed comparison of these differences would help researchers and traditional medical practitioners to better understand the indications of fecal medicines and promote their development and utilization. In this study, we compared the similarities and differences of therapeutic uses of Wu-Ling-Zhi and Hei-Bing-Pian in different traditional medical systems, including TCM, Tibetan EM, Korean EM, Dai EM, Yao EM, Tujia EM, $\mathrm{Nu}$ EM, and Mongolian EM. Additional details are provided in Table 6 . The results indicate that Wu-Ling-Zhi is commonly used to treat amenorrhea and dysmenorrhea in most traditional medical systems. However, its therapeutic uses also have some obvious differences in different medical systems. For example, in the Tibetan EM, Wu-Ling-Zhi can be used to treat stomachache, whereas in the Mongolian EM, it is mainly used to treat diarrhea, gout and itching. Moreover, Wu-Ling-Zhi can treat cold, whooping cough and fever in the Nu EM. Hei-Bing-Pian has the same therapeutic use in TCM and Tibetan EM systems. It is widely used in both systems to treat dyspepsia, biliary diseases, plague and distending pain in the stomach. There is no difference in the therapeutic use of Hei-Bing-Pian in the two medical systems.

\section{Conclusion and future perspectives}

Chinese traditional medicine is an important part of the world's medical system. In long-term clinical practice, ancient Chinese doctors have accumulated invaluable experience in the use of fecal medicines. As shown in Tables 1 and 2, some fecal medicines have been found to be effective in treating amenorrhea, dysmenorrhea dyspepsia, diarrhea, fever, and stomachache. These traditional medication knowledge are valuable assets. Currently, some fecal medicines (e.g., Wu-Ling-Zhi, Jiu-Fen and Hei-Bing-Pian) are still used in clinical practice. A total of 76 preparations containing fecal medicines were 
recorded in the latest official drug standards (Table 5). Extensive clinical application demonstrates the role and value of fecal medicines in Chinese medical systems. Moreover, Wu-Ling-Zhi extracts and its chemical constituents have been proved to possess a wide spectrum of biological activities, such as anti-inflammatory, anticoagulative and antioxidant effects (Tables 3 and 4). Some possible molecular mechanisms have also been revealed. The results of these modern pharmacological studies provide some evidences to prove the scientific nature of fecal medicines. However, most fecal medicines still lack experimental evidences. For example, Jiu-Fen is a commonly used Tibetan medicine. However, so far, no biological activities or active ingredients have been reported for this drug. Therefore, in order to better develop and utilize these fecal medicines, more in vivo pharmacological studies and even clinical evaluations should be performed to prove their scientific and medicinal value.

Fortunately, an in-depth study of gut microbiota has provided an opportunity to interpret the scientific connotation of some traditional fecal medicines, such as the yellow soup. This soup is a fresh fecal suspension of Homo sapiens commonly used to treat food poisoning, severe diarrhea, heat toxins, and unconsciousness due to high fever. Zhang et al. [44, 45] believe that the efficacy of yellow soup is mainly caused by the gut microbiota from fresh fecal water, and its principle for treating diseases is similar to the fecal microbiota transplantation method of modern medicine. Therefore, reconstructing the gut microbiota of patients may be the mechanism of action of fresh fecal medicines for treating diseases.

However, most fecal medicines are derived from dry feces (e.g., Wu-Ling-Zhi) or processed products (e.g., Hei-Bing-Pian). During drying and processing, these fecal medicines lose the living microbiota. Therefore, their mechanisms for treating diseases may be different from fresh feces. Feces are intestinal excretions of humans or animals. The chemical constituents in feces are mainly derived from the host or dietary metabolites. These metabolites may be the key active constituents of fecal medicinal materials. For example, the terpenoids, flavonoids and lignans contained in Wu-Ling-Zhi are closely related to the foods eaten by Trogopterus xanthipes (e.g., Platycladus orientalis leaves, Pinus tabulaeformis bark, and peach kernels). These diet-derived metabolites may be the pharmacologically active ingredients of Wu-Ling-Zhi. Moreover, some bile acids (e.g., deoxycholic acid, lithocholic acid and taurocholic acid) have been found in Wu-Ling-Zhi and Hei-Bing-Pian [21]. These bile acids are the final metabolites of cholesterol under the common metabolism of liver and gut microbiota. Bile acids are endocrine-signaling molecules that regulate metabolic processes, including glucose, lipid and energy homeostasis, by regulating gut microbiota or activating bile acid receptors, such as the farnesoid $\mathrm{X}$ receptor (FXR) and G protein-coupled bile acid receptor 1 [46-48]. Distrutti et al. [49] reported that bile acidsactivated receptors are targets for maintaining intestinal integrity. Gadaleta et al. [50] found that FXR activation could prevent chemically induced intestinal inflammation with an improvement of colitis symptoms and inhibition of epithelial permeability. In addition, bile acids can also regulate cardiovascular functions via receptordependent and -independent mechanisms [51]. These findings provide a rationale to explore the mechanisms of Hei-Bing-Pian and Wu-Ling-Zhi in the treatment of gastrointestinal and cardiovascular diseases, respectively.

With the continuous development of science and technology, some unique but sometimes incomprehensible drugs in traditional medical systems will gradually be recognized. In this study, we provide the first comprehensive data compilation of fecal medicines used in Chinese traditional medical systems. The information recorded in ancient monographs and drug standards, such as original species, traditional uses and indications, can provide a good reference for the development and utilization of fecal medicines. In view of the current research status of fecal medicines, future research may focus on the following aspects: (1) applying multidisciplinary methods to further prove their effectiveness and medicinal value, (2) revealing their active ingredients associated with clinical efficacy using phytochemical and pharmacodynamic methods, and (3) elucidating the mechanisms of action of fecal medicines based on gut microbiota or receptormediated signaling pathways.

\section{Abbreviations}

TCM: traditional Chinese medicine; TTM: traditional Tibetan medicine; EM: ethnic medicine.

\section{Acknowledgements}

Not applicable.

\section{Authors' contributions}

HD, T-TK: conducted the research, collected the data, and wrote the paper; SQ, TX: collected, organized, and analyzed the data; C-L GH: collected the Tibetan fecal medicines; and YZ, GF: conceived and designed the study. All authors read and approved the final manuscript.

\section{Funding}

This research was support by the National Key Research and Development Program of China (No. 2017YFC1703900) and National Natural Science Foundation of China (No. 81874370).

\section{Availability of data and materials}

The datasets used and/or analysed during the current study are available from the corresponding author on reasonable request.

Ethics approval and consent to participate Not applicable. 


\section{Consent for publication}

Not applicable.

\section{Competing interests}

The authors declare that they have no competing interests.

\section{Author details}

${ }^{1}$ School of Pharmacy, Chengdu University of Traditional Chinese Medicine, Chengdu 611137, China. ${ }^{2}$ School of Ethnic Medicine, Chengdu University of Traditional Chinese Medicine, Chengdu 611137, China. ${ }^{3}$ School of Foreign Language, Chengdu University of Traditional Chinese Medicine, Chengdu 611137, China.

Received: 22 July 2019 Accepted: 2 September 2019

Published online: 13 September 2019

\section{References}

1. Ge H. Zhou Hou Bei Ji Fang. Tianjing: Tianjin Science and Technology Press; 2000

2. Yutuo YDGB. The Four Medical Tantras. Shanghai: Shanghai Scientific and Technical Publishers; 1987.

3. Li SZ. Compendium of Materia Medica. Beijing: People's Medical Publishing House; 1979.

4. Dimaer DZPC. Jing Zhu Materia Medica. Shanghai: Shanghai Scientific and Technical Publishers; 1988.

5. Chinese Pharmacopoeia Commission. Pharmacopoeia of the People's Republic of China, Part 1. 1990th ed. Beijing: People's Medical Publishing House; 1990.

6. Health Bureau of Tibet, Qinghai, Sichuan, Gansu, Yunnan, Xinjiang Tibetan medicine standards. Xining: Qinghai People's Publishing Press; 1979.

7. Chinese Pharmacopoeia Commission. Pharmacopoeia of the People's Republic of China, Part 1. 2015th ed. Beijing: The Medicine Science and Technology Press of China; 2015.

8. Lu DX. Kai Bao Ben Cao. Hefei: Anhui Science and Technology Press; 1998.

9. Liao XY. Sheng Nong Ben Cao Jing Shu. Beijing: Traditional Chinese Medicine Classics Publishing House; 2002

10. Numata A, Yang P, Takahashi C, Fujiki R, Nabae M, Fujita E. Cytotoxic triterpenes from a Chinese medicine, Goreishi. Chem Pharm Bull. 1989;37(3):648-51.

11. Numata A, Takahashi C, Miyamoto T, Yoneda M, Yang PM. New triterpenes from a Chinese medicine, Goreishi. Chem Pharm Bull. 1990;38(4):942-4.

12. Zhao J, Zhu H, Zhou X, Yang T, Wang Y, Su J, et al. Diterpenoids from the feces of Trogopterus xanthipes. J Nat Prod. 2010;73(5):865-9.

13. Yang NY, Tao WW, Zhu M, Duan JA, Jiang JG. Two new isopimarane diterpenes from the feces of Trogopterus xanthipes. Fitoterapia. 2010;81(5):381-4

14. Yang NY, Tao WW, Duan JA. Antithrombotic flavonoids from the faeces of Trogopterus xanthipes. Nat Prod Res. 2010;24(19):1843-9.

15. Baek S, Shim S. Isolation and structure determination of four new neolignans from Trogopterorum faeces. Planta Med. 2012;78(11):323.

16. Baek S, Xia X, Min BS, Park C, Shim SH, Trogopterins A-C. Three new neolignans from feces of Trogopterus xanthipes. Beilstein J Org Chem. 2014; 10:2955-62.

17. Yang NY, Tao WW, Duan JA, Guo JM, Cao LL. Four new fatty acid esters from the feces of Trogopterus xanthipes. Lipids. 2009;44(9):849-53.

18. Li Q, Lu YR, Lu XZ, Tao Y. Studies on the chemical constituents of faces Trogopterus. China J Chin Mater Med. 1999;34(8):514-6.

19. Yang DM, Su SW, Li X, Zhu TR. Study on bioactive constituents from the extracts of Trogopterus xanthipes Milne-Edwards. Acta Pharm Sin. 1987;22(10):756-60.

20. Wei Y, Zhang X, Huang AJ. Analysis of the volatile components in trogopterorum feces by capillary gas chromatography and gas chromatography/mass spectrometry. Chin J Anal Chem. 2001;29(2):195-8.

21. Yerigui, Wu XH, Wang XJ, Ma CM. Quantification of bile acids in traditional animal medicines and their preparations using ultra high-performance liquid chromatography-mass spectrometry in the multiple reaction monitoring mode. Anal Sci. 2016;32(5):499-503.
22. Jiao Y. Study on quality control method of faeces trogopterori. Shengyang: Shenyang Pharmaceutical University; 2009.

23. Chen $X Q$, Jia WJ, Zhou ZL, Li H, Nan F, She L. Study on the quality standard of Faeces trogopterori. Northwest Pharm J. 2019;34(4):469-73.

24. Kim BJ, Ham KW, Park KB, Kim DH, Jo BY, Cho CR, et al. Inhibitory effect of extract of trogopterorum faeces on the production of inflammatory mediaters. Korea J Herbol. 2009;24(3):153-60.

25. Wang SJ, Song LY, Liu YL, Zhang XY, Xu XS, Yu L. Study on anti-inflammatory effect of Wu-Ling-Zhi. J Shenyang Coll Pharm. 1994;11(1):49-53.

26. Wang XW, Liu WZ, Shao YB. Comparative study on the protective effect of the extract of feces trogopterus on gastric mucosa. Yunnan J Tradit Chin Med Mater Med. 2003;25(1):30-1.

27. Bu SM, Jia MH, Qu YB. Protective action of Trogopterus xanthipes nightsoil on the cerebral ischemia in mice and rats. J Shanxi Univ. 2000;23(3):257-9.

28. Tang XG, Huang WQ, Jiang LK. Study on anti-inflammatory effect of faces trogopterus in experiment alarterosclerotic rats. Pharmacol Clin Chin Mater Med. 2009;25(1):35-8.

29. Song YR, Kim JE, Yang SJ, Park KM, Jung SJ, Cho SH. Effects of trogopterorum faeces on the apoptostic cell death in breast cancer cells. J Korean Obstet Gynecol. 2015;28(1):46-57.

30. Li Q, Li HJ, Xu T, Du H, Huan Gang CL, Fan G, et al. Natural medicines used in the traditional tibetan medical system for the treatment of liver diseases. Front Pharmacol. 2018;9:29-45.

31. Disi SJJC. Tibetan medical Thangka of The Four Medical Tantras. Lasa: The Tibet people's Publishing House; 2008.

32. Mao JZ. The treasure house of Tibetan medicine prescription. Lanzhou: Gansu Ethnic Publishing House; 2014.

33. Wu HC. The annotation of commonly used Tibetan patent drug. Xining: Qinghai people's Publishing House; 2002.

34. Wang BQ. National standards for Tibetan Medicine, vol. 1-3. Beijing: Chinese Medical Audio-Visual Publishing House; 2004.

35. Chinese Pharmacopoeia Commission. Drug standards of Tibetan medicines. Beijing: Ministry of Health of the People's Republic of China; 1995.

36. Editorial Board of Chinese Herbalism. Chinese herbalism for Tibetan medicine. Shanghai: Shanghai Scientific and Technical Publishers; 2002.

37. Cui Y, Yi R, Weng H, Zhao YY. Determination of trace Titanium in HeiBing-Pian of by spectrophotometric method. J Inner Mongolia Univ Natl. 2008;23(5):517-8

38. Zhao YY, Ba T, Zhao YQ. Determination and pharmacodynamic analysis of iron and other inorganic elements in Mongolian Medicine Heibingpian and its Formulas. J Med Pharm Chin Minor. 2000;6(1):46-7.

39. Chang L, Dong M, Liu J. Study on quality control of Hei-Bing-Pian. J Med Pharm Chin Minor. 2016;16(12):31-2.

40. Lin J, Chang L, Bai YF, Qi MY. Effect research of Hei-bing-pian of special Mongolia herbal for experimental colitis in rats. J Med Pharm Chin Minor. 2009;22(4):40-2.

41. Cai F, Chen GR, Bai YF. Effect of Hei-bing-pian on intestinal smooth muscle function in animals. J Med Pharm Chin Minor. 2008;37(3):59-60.

42. Bai YF, Qiqige, Feng GQ. Effect of Hei-bing-pian from Mongolian medicine on gastrointestinal function of animals. J Med Pharm Chin Minor. 2005; 11:125-6.

43. Li RP, Chang L, Bai YF. Long-term toxicity of Mongolian medicine Heibing-pian on rats. J Med Pharm Chin. 2011;37(4):53-4.

44. Zhang FM, Luo WS, Shi Y, Fan ZN, Ji GZ. Should we standardize the 1,700 year old fecal microbiota transplantation? Am J Gastroenterol. 2012;107(11):1755.

45. Zhang FM, Cui BT, He XX, Nie YQ, Wu KC, Fan DM, et al. Microbiota transplantation: concept, methodology and strategy for its modernization. Protein Cell. 2018;9(5):462-73.

46. Khurana S, Raufman JP, Pallone TL. Bile acids regulate cardiovascular function. Clin Transl Sci. 2011;4(3):210-8.

47. Stefano F, Andrea M, Giuseppe P, Sabrina C. Bile acid activated receptors: targeting TGR5 and farnesoid-X-receptor in lipid and glucose disorders. Trends Pharmacol Sci. 2009;30(11):570-80

48. Jia W, Xie G, Jia W. Bile acid-microbiota crosstalk in gastrointestinal inflammation and carcinogenesis. Nat Rev Gastroenterol Hepatol. 2017;15(2):111-21.

49. Distrutti E, Santucci L, Cipriani S, Renga B, Schiaroli E, Ricci P, et al. Bile acid activated receptors are targets for regulation of integrity of gastrointestinal mucosa. J Gastroenterol. 2015;50(7):707-19. 
50. Gadaleta RM, van Erpecum KJ, Oldenburg B, Willemsen ECL, Renooij W, Murzilli $S$, et al. Farnesoid $X$ receptor activation inhibits inflammation and preserves the intestinal barrier in inflammatory bowel disease. Gut. 2011;60(4):463-72.

51. Molinaro A, Wahlström A, Marschall HU. Role of bile acids in metabolic control. Trends Endocrinol Metab. 2018;29(1):31-41.

52. Editorial Board of Chinese Herbalism. Chinese Materia Medica. Shanghai: Shanghai Science and Technology Press; 1999.

53. Editorial Board of Animal medicinal materials of China. Medicinal animal annals of China. Tianjing: Tianjin Science and Technology Press; 1983.

54. Zhang L. Beng Jing Feng Yuan. Beijing: China Press of Traditional Chinese Medicine; 1996.

55. Nanjing University of TCM. The dictionary of traditional chinese medicine. Shanghai: Shanghai Science and Technology Press; 2006.

56. The Company of Chinese Medicinal Materials. Chinese traditional medicine resources annals. Beijing: The Science Publishing Company; 1994

57. Deng ML, Gao SX. The medicinal animal of China. Changchun: Jilin People's Publishing House; 1981.

58. Tao HJ. Ming Yi Bie Lu. Beijing: People's Medical Publishing House; 1986.

59. Luo DS. Chinese Tibetan Materia Medica. Beijing: Ethnic Publishing House; 1997.

60. Jia MR, Zhang Y. Dictionary of Chinese ethnic medicine. Beijing: China Medical Science Press; 2016.

61. Editorial Board of Chinese Herbalism. Chinese Materia Medica-Uighur medicine. Shanghai: Shanghai Science and Technology Press; 2005.

62. Editorial Board of Chinese Herbalism. Chinese Materia Medica-Mongolian medicine. Shanghai: Shanghai Scientific and Technical Publishers; 2004.

63. Qin XY, Luo YJ, Gao ZG. Yao ethnic medicinals in China. Beijing: Nationalities Publishing House; 2002.

64. Zhu GH, Du J, Zhang JM. Tujia minority medicine. Beijing: Publishing House of Ancient Chinese Medical Books; 2006

65. Tudan CR. Medical encyclopedia of China_-Tibetan medicine. Shanghai: Shanghai Scientific and Technical Publishers; 1999.

66. Disi SJJC. Lan Liu Li. Shanghai: Shanghai Scientific and Technical Publishers; 2012

67. Jia MR, Li XW. The annals of Chinese ethnic medicine. Beijing: China Medical Science Press; 2005

68. Fogo AS, Antonioli E, Calixto JB, Campos AH. Tormentic acid reduces vascular smooth muscle cell proliferation and survival. Eur J Pharmacol. 2009:615(1):50-4.

69. Kim IT, Ryu S, Shin JS, Choi JH, Park HJ, Lee KT. Euscaphic acid isolated from roots of Rosa rugosa inhibits LPS-induced inflammatory responses via TLR4-mediated NF-KB inactivation in RAW 264.7 macrophages. J Cell Biochem. 2012:113(6):1936-46.

70. Jiang X, Li T, Liu RH. 2a-hydroxyursolic acid inhibited cell proliferation and induced apoptosis in MDA-MB-231 human breast cancer cells through the p38/MAPK signal transduction pathway. J Agric Food Chem. 2016;64(8):1806-16.

71. Schinella G, Aquila S, Dade M, Giner R, del Carmen Recio M, Spegazzini E, et al. Anti-inflammatory and apoptotic activities of pomolic acid isolated from Cecropia pachystachya. Planta Med. 2008;74(3):215-20.

72. Woźniak Ł, Skąpska S, Marszałek K. Ursolic acid-a pentacyclic triterpenoid with a wide spectrum of pharmacological activities. Molecules. 2015;20(11):20614-41

73. Li CH, Yang ZF, Zhai CY, Qiu WW, Li DL, Yi ZF, et al. Maslinic acid potentiates the anti-tumor activity of tumor necrosis factor a by inhibiting NF-KB signaling pathway. Mol Cancer. 2010;9(1):73-86.

74. Rodríguez JA, Theoduloz C, Yáñez T, Becerra J, Schmeda-Hirschmann G. Gastroprotective and ulcer healing effect of ferruginol in mice and rats: assessment of its mechanism of action using in vitro models. Life Sci. 2006;78(21):2503-9.

75. Li SP, Zhang QY, Li PW. Protective effects of epifriedelinol in a rat model of traumatic brain injury assessed with histological and hematological markers. Transl Neurosci. 2018;9(1):38-42.

76. Shim SY, Lee SG, Lee M. Biflavonoids isolated from Selaginella tamariscina and their anti-inflammatory activities via ERK $1 / 2$ signaling. Molecules. 2018;23(4):926-38.

77. Su CF, Yang CB, Gong M, Ke YY, Yuan PP, Wang XL, et al. Antidiabetic activity and potential mechanism of amentoflavone in diabetic mice. Molecules. 2019;24(11):2184-98.
78. Hee KJ, Minjeong K, Min KJ, Kyung LM, Jun SS, Young PK. Afzelin suppresses proinflammatory responses in particulate matter-exposed human keratinocytes. Int J Mol Med. 2019;43(6):2516-22.

79. Hu XT, Ding C, Zhou N, Xu C. Quercetin protects gastric epithelial cell from oxidative damage in vitro and in vivo. Eur J Pharmacol. 2015;754:115-24

80. Jang J, Kim SM, Yee SM, Kim EM, Lee EH, Choi HR, et al. Daucosterol suppresses dextran sulfate sodium (DSS)-induced colitis in mice. Int Immunopharmacol. 2019;72:124-30.

81. Loizou S, Lekakis I, Chrousos GP, Moutsatsou P. $\beta$-sitosterol exhibits antiinflammatory activity in human aortic endothelial cells. Mol Nutr Food Res. 2010;54(4):551-8.

82. Cao JS. Anti-inflammatory actions of cholic acid and its effect on pharmacology and histology of respiratory system. Hohhot: Inner Mongolia Agricultural University; 2001.

83. Chen X, Mellon RD, Yang L, Dong H, Oppenheim JJ, Howard OMZ. Regulatory effects of deoxycholic acid, a component of the anti-inflammatory traditional Chinese medicine Niuhuang, on human leukocyte response to chemoattractants. Biochem Pharmacol. 2002;63(3):533-41.

84. Martínez Moya P, Romero Calvo I, Requena P, Hernández Chirlaque C, Aranda CJ, González R, et al. Dose-dependent antiinflammatory effect of ursodeoxycholic acid in experimental colitis. Int Immunopharmacol. 2013;15(2):372-80.

85. Li PF, Xue Y, Guan H. Study on anti-inflammatory effect of taurocholic acid. J Inner Mongolia Agric Univ. 2007;28(1):1-5.

86. Cheng ZA, Li QM, Wang XW. Effect of faeces trogopterori extract on experimental gastric ulcer and gastric secretion in rat. J Sun Yat-sen Univ. 1997;18(1):47-50.

87. Chen C, Wang FQ, Xiao W, Xia ZN, Hu G, Wan JB, et al. Effect on platelet aggregation activity: extracts from 31 Traditional Chinese Medicines with the property of activating blood and resolving stasis. J Tradit Chin Med. 2017;37(1):64-75

88. Wang SJ, Liu YL, Song LY, Wang M, Zhu Y, Wang AH. A pharmacological study on anti-platelet aggregation of WEFT. J Shenyang Coll Pharm. 1994;11(4):246-9.

89. Zhai QL. The neuro-protective effects of water extract of faces trogopterori on transient MCAO rats. Biomed Res. 2016;27(3):972-6.

90. Chinese Pharmacopoeia Commission. Drug standards of Mongolian medicine. Beijing: Ministry of Health of the People's Republic of China; 1992.

91. Lende AB, Kshirsagar AD, Deshpande AD, Muley MM, Patil RR, Bafna PA, et al. Anti-inflammatory and analgesic activity of protocatechuic acid in rats and mice. Inflammopharmacology. 2011;19(5):255-63.

92. Chinese Pharmacopoeia Commission. Drug standards of Uygur medicine Urumqi: XinJiang Medical Science and Technology Publishing House; 1999.

\section{Publisher's Note}

Springer Nature remains neutral with regard to jurisdictional claims in published maps and institutional affiliations.

Ready to submit your research? Choose BMC and benefit from

- fast, convenient online submission

- thorough peer review by experienced researchers in your field

- rapid publication on acceptance

- support for research data, including large and complex data types

- gold Open Access which fosters wider collaboration and increased citations

- maximum visibility for your research: over 100M website views per year

At BMC, research is always in progress.

Learn more biomedcentral.com/submissions 